\title{
IMPLEMENTASI MODEL PROBLEM BASED LEARNING BERBANTUAN ALAT PERAGA UNTUK MENINGKATKAN AKTIVITAS DAN HASIL BELAJAR FISIKA SISWA KELAS VIII SMPN 22 MATARAM TAHUN PELAJARAN 2014/2015
}

\author{
Baiq Ewik Jiniarti ${ }^{1}$, Hj. Hairunnisyah Sahidu ${ }^{2}$, Ni Nyoman Sri Putu Verawati ${ }^{2}$ \\ ${ }^{1)}$ Program Studi Pendidika Fisika \\ 2) Program Studi Pendidika Fisika FKIP \\ Universitas Mataram. \\ Mataram Indonesia. \\ Email: Ewikbaiq@gmail.com
}

\begin{abstract}
This research is a Classroom Action Research (CAR) which aims to increase the students activities and physics learning outcomes with implementation problem based learning model assisted by props in grade VIIIA SMPN 22 Mataram 2014/2015. This classroom action research conducted by two cycles, with each cycle consisting of two meetings. Action research consists of four stages: planning, implementation, observation and evaluation, and reflection. The implementation of classroom action research was successful because it obtained an average score of students learning activities from the first cycle to the second cycle was on active criterion to be very active with average scores of 16,875 to be 22,75. Cognitive learning outcomes of students with the average value of the first cycle of 74,13 with classical completeness $73,91 \%$ increased with the average value of second cycle of 79,35 with classical completeness $86,96 \%$. Affective students learning outcomes from the first cycle to the second cycle with an average value of 66,195 to 78,95 on the criteria good enough to be good. Psychomotor students learning outcomes from the first cycle to the second cycle an average value of 71,63 to 85,655 are the criteria enough skilled become skilled. Thus, this research can be concluded by implementation of problem based learning model aided by props can increase students activities and learning outcomes of phyics grade VIIIA SMPN 22 Mataram in academic year 2014/2015.
\end{abstract}

Keywords: problem based learning model, props, activities and learning outcomes

\section{PENDAHULUAN}

Ilmu pengetahuan dan teknologi berkembang dengan pesat. Setiap ilmu pengetahuan dan teknologi yang berkembang memberikan manfaat bagi kehidupan manusia. Dengan menggunakan berbagai macam pengetahuannya, manusia dapat memperluas wawasannya. Ilmu Pengetahuan Alam (IPA) ikut andil dalam perkembangan tersebut. Pada hakikatnya Ilmu Pengetahuan Alam (IPA) merupakan suatu produk, proses, dan sikap [1]. Hasil-hasil penemuan dari berbagai kegiatan penyelidikan dikumpulkan dan disusun secara sistematik menjadi sebuah kumpulan pengetahuan yang disebut sebagai produk. Kumpulan pengetahuan itu meliputi fakta, konsep, prinsip, hukum, rumus, teori serta model. IPA sebagai proses meliputi pemahaman mengenai bagaimana informasi ilmiah diperoleh, diuji, dan divalidasikan. Proses penemuan, pengamatan, pengukuran, dan penyelidikan ilmiah yang dilakukan memerlukan proses mental dan sikap ilmiah.
Secara umum IPA meliputi tiga bidang ilmu dasar, yaitu biologi, fisika, dan kimia.Fisika merupakan salah satu cabang dari Ilmu Pengetahuan Alam (IPA) yang mempelajari gejala dan peristiwa atau fenomena yang terjadi dalam benda-benda mati dan bersifat abstrak. Belajar fisika tidak terlepas dari hakikat IPA oleh karena itu, pada proses pembelajaran tersebut, seorang guru harus mampu memilih dan menggunakan berbagai model pembelajaran, media yang tepat serta menciptakan iklim pembelajaran yang kondusif sehingga kriteria ketuntasan minimal (KKM) yang telah ditetapkan oleh sekolah tercapai.

Berdasarkan hasil wawancara dengan beberapa siswa dan guru bidang studi IPA serta observasi yang dilakukan di SMPN 22 Mataram khususnya di kelas VIII, terdapat beberapa masalah dalam kegiatan pembelajaran antara lain: (1) model pembelajaran yang digunakan masih belum cukup untuk memfasilitasi pemahaman siswa terutama dalam memecahkan permasalahan yang sering ditemui dalam kehidupan sehari-hari, sehingga 
menyebabkan pengetahuan yang diperoleh siswa kurang bermakna; (2) materi pelajaran fisika oleh sebagian siswa merupakan pelajaran yang relatif sulit, terdiri dari sekumpulan rumus yang harus dihapalkan, sehingga menyebabkan pelajaran fisika kurang diminati siswa; (3) kurangnya aktivitas siswa dalam proses pembelajaran karena masih terfokus pada guru, sehingga guru yang mendominasi dalam proses pembelajaran; dan (4) kurangnya pemanfaatan alat peraga yang sudah ada. Permasalahan-permasalahan tersebut, menyebabkan pemahaman siswa terhadap konsep-konsep fisika yang bersifat abstrak masih rendah, hal ini dapat terlihat dari hasil belajar fisika siswa kelas VIIIA SMPN 22 Mataram belum berhasil mencapai nilai KKM yang sudah ditetapkan sekolah yaitu 75 dengan pencapaian nilai rata-rata kelas sebesar 60,20 dan dikatakan tidak tuntas.

Model Problem Based Learning merupakan salah satu model pembelajaran yang melibatkan siswa untuk memecahkan suatu masalah melalui metode ilmiah sehingga siswa memperoleh pengetahuan dan memiliki keterampilan dalam memecahkan masalah. Selain itu, untuk membantu memperkuat siswa memahami konsep-konsep fisika, serta memudahkan siswa dalam memahami materi, maka perlu didukung dengan penggunaan media berupa alat peraga, sehingga diharapkan aktivitas dan hasil belajar meningkat. Berdasarkan hasil penelitian Kharida dkk, yaitu rata-rata nilai hasil belajar kognitif siswa yang diajarkan dengan model Problem Based Learning mengalami peningkatan secara signifikan dari siklus 1 ke siklus 2 dengan besar peningkatan (Gain) hasil belajar adalah $26 \%$ dan ketuntasan belajar secara klasikal 86,67\% . Selain itu, aktivitas belajar siswa dan guru meningkat ketika menggunakan model PBL dengan peningkatan aktivitas belajar siswa sebesar 33\% [2]. Hasil penelitian lainnya yang dilakukan oleh Hapsoro dkk, menunjukkan bahwa penerapan pembelajaran berdasarkan masalah berbantuan alat peraga memberikan pengaruh dan hasil yang lebih baik dari pada pembelajaran konvensional dalam hal peningkatan hasil belajar kognitif dan aktivitas siswa[3]. Sejalan dengan hal di atas, Sambudi dkk, mengatakan bahwa penggunaan alat peraga dapat meningkatkan hasil belajar kognitif siswa. Peningkatan ini dapat terlihat dari kenaikan nilai sebelum dilakukan tindakan sebesar 26,00 dengan ketuntasan belajar klasikal hanya $0 \%$ dan setelah dilakukan pembelajaran pada siklus I, nilai rata-rata sebesar 71,7 dengan ketuntasan belajar klasikal mencapai $71,4 \%$ sedangkan pada siklus II nilai ratarata menjadi 79,3 dengan ketuntasan belajar klasikal mencapai 90,5\%[4].

\section{Tinjauan Pustaka}

\section{A. Model Pembelajaran}

Model pembelajaran adalah tiruan atau contoh kerangka konseptual yang melukiskan prosedur pembelajaaran secara sistematis dalam mengelola pengalaman belajar siswa agar tujuan belajar tertentu yang diinginkan dapat tercapai [5].

Model pembelajaran mempunyai empat ciri khusus yang tidak dimiliki oleh strategi, metode atau prosedur, yaitu (1) rasioanl teoretik logis yang disusun oleh para pencipta atau pengembangnya, (2) landasan pemikiran tentang apa dan bagaimana siswa belajar (tujuan pembelajaran yang akan dicapai), (3) tingkah laku mengajar yang diperlukan agar model tersebut dapat dilaksanakan dengan berhasil, dan (4) lingkungan belajar yang diperlukan agar tujuan pembelajaran itu dapat tercapai [6].

Dari uraian mengenai ciri-ciri khusus model pembelajaran di atas, dapat dijelaskan bahwa setiap model pembelajaran berdasarkan pada teori pendidikan dan teori belajar dari para ahli tertentu, memiliki tujuan tertentu, memiliki sintaks yang berbeda- beda yang harus dikuasai oleh guru dan dapat menerapkan berbagai keterampilan mengajar sebagai upaya menciptakan kondisi lingkungan yang dapat memebelajarkan siswa dan dapat mendorong siswa belajar untuk mencapai tujuan pembelajaran.

Pada proses pembelajaran, guru diharapkan dapat menerapkan suatu model pembelajaran yang sesuai, sehingga tujuan pembelajaran dapat dicapai secara optimal. Pemilihan model pembelajaran dapat memacu siswa untuk lebih aktif belajar terutama dalam keterampilan memecahkan masalah. Salah satu model pembelajaran yang dapat diterapkan khususnya pada materi cahaya adalah model Problem Based Learning.

\section{B. Model Problem Based Learning(PBL)}

\section{Pengertian Model Problem Based Learning \\ Model Problem Based Learning} sebagai suatu model pembelajaran yang didasarkan pada banyaknya permasalahan 
yang membutuhkan penyelidikan autentik yakni penyelidikan yang membutuhkan penyelesaian nyata dari permasalahan yang nyata [6]. Pendapat lain menyatakan bahwa Problem Based Learning merupakan inovasi dalam pembelajaran karena dalam PBL kemampuan berpikir siswa betul-betul dioptimalkan melalui proses kerja kelompok atau tim yang sistematis, sehingga siswa dapat memberdayakan, mengasah, menguji, dan mengembangkan berpikirnya secara berkesinambungan [7].

\section{Karaktersitik Model Problem Based Learning (PBL)}

Karakteristik dalam Problem Based Learning, yaitu (a) permasalahan menjadi startingpoint dalam pembelajaran, (b) permasalahan yang digunakan adalah permasalahan kontekstual, (c) permasalahan yang digunakan membutuhkan perspektif, (d) permasalahan yang digunakan membutuhkan identifikasi belajar, (e) belajar pengarahan diri merupakan hal utama bagi siswa, (f) pemanfaatan sumber pengetahuan yang beragam, (g) belajar adalah kolaboratif, komunikaif, dan kooperatif, (h) pengembangan keterampilan inquiry dan pemecahan masalah, dan (i) melibatkan evaluasi review pengalaman siswa dan proses belajar [7].

\section{Pelaksanaan Model Problem Based Learning (PBL)}

Pelaksanaan proses pembelajaran dalam penelitian ini disesuaikan dengan sintaks dari model problem based learning dengan sintaks berikut ini: [8]

Tabel 1. Sintak Model Problem Based Learning

\begin{tabular}{ll}
\hline Fase & Perilaku Guru \\
Fase 1: & Guru membahas tujuan \\
Memberikan & pembelajaran, \\
orientasi tentang & mendeskripsikan dan \\
permasalahannya & memotivasi siswa untuk \\
kepada siswa & $\begin{array}{l}\text { terlibat dalam kegiatan } \\
\text { mengatasi masalah. }\end{array}$ \\
\hline
\end{tabular}

\begin{tabular}{ll}
\hline Fase & Perilaku Guru \\
\hline Fase 2: & Guru membantu siswa \\
untuk mendefinisikan \\
Mengorganisasika & dan mengorganisasikan \\
n siswa untuk & tugas-tugas belajar \\
meneliti. & terkait dengan \\
& permasalahannya. \\
\hline Fase 3: & Guru mendorong siswa \\
Membantu & untuk mendapatkan \\
investigasi & informasi yang tepat, \\
mandiri dan & melaksanakan \\
kelompok. & eksperimen, dan \\
& mencari penjelasan dan \\
\hline Fase 4: & solusi. \\
Mengembangkan membantu siswa \\
dan & dalam merencanakan \\
mempresentasika & dan menyiapkan hasil- \\
n hasil & lasil yang tepat, seperti \\
& $\begin{array}{l}\text { dan model-model dan } \\
\text { membantu mereka untuk }\end{array}$ \\
& menyampaikan kepada \\
& orang lain. \\
\hline Fase 5: & Guru membantu siswa \\
Menganalisis dan & untuk melakukan \\
mengevaluasi & refleksi terhadap \\
proses mengatasi & investigasinya dan \\
masalah. & proses-proses yang \\
& mereka gunakan. \\
\hline & \multicolumn{2}{c}{. } \\
\hline
\end{tabular}

\section{Alat Peraga}

Alat peraga merupakan suatu alat bantu yang dipergunakan oleh pembelajar untuk memperagakan materi pelajaran [9]. Pendapat lain mengatakan bahwa alat peraga digunakan oleh guru untuk memberi penekanan pada informasi, memberikan stimulasi pada perhatian, dan memfasilitasi proses pembelajaran, dari pendapat beberapa ahli di atas, maka peneliti dapat menyimpulkan bahwa alat peraga merupakan suatu alat bantu atau media yang dipergunakan untuk memperagakan materi pelajaran sehingga materi pembelajaran yang disampaikan lebih mudah dipahami oleh siswa [9].

Terdapat enam langkah yang perlu dilakukan guru pada saat mengajar menggunakan media atau alat peraga yaitu, (1) merumuskan tujuan, (2) memilih media yang sesuai, (3) memotivasi siswa agar berpartisipasi aktif, (4) menjelaskan penyajian media atau alat peraga yang digunakan, (5) memberi kesempatan kepada siswa untuk praktik menggunakan media atau alat peraga, dan (6) 
mengevaluasi atau menilai sejauh mana pengaruh media terhadap keberhasilan siswa [10].

\section{Aktivitas dan Hasil Belajar}

Kegiatan paling utama yang menjadi tujuan siswa datang ke sekolah adalah belajar. Proses belajar yang kompleks akan mengakibatkan seseorang memiliki keterampilan, pengetahuan, sikap, dan nilai. Siswa akan mendapatkan informasi lebih bermakna dari aktivitas yang mereka lakukan selama proses pembelajaran yang mempengaruhi hasil belajar siswa.

\section{Aktivitas Belajar}

Kegiatan yang dilakukan untuk mencapai pengetahuan, keterampilan, nilai dan sikap. Fungsi dan tugas guru sebagai fasilitator dan mediator dalam pembelajaran yang dapat mengikutsertakan siswa secara aktif, baik sebagai individu ataupun sebagai kelompok [11]

Adapun macam-macam aktivitas belajar siswa yang digolongkan oleh Paul B. Diedrich yaitu, aktivitas visual (Visual activities), aktivitas Lisan (Oral activities), aktivitas mendengarkan (Listening activities), aktivitas menulis (Writing activities), aktivitas menggambar (Drawing activities), aktivitas metrik (Motor activities), aktivitas mental (Mental activities), aktivitas emosional (Emotional activities) [11].

\section{Hasil Belajar}

Hasil belajar dapat dijelaskan dengan memahami dua kata yang membentuknya, yaitu "hasil" dan "belajar". Pengertian hasil (product) menunjuk pada suatu perolehan akibat dilakukannya suatu aktivitas atau perolehan yang mengakibatkan berubahnya input secara fungsional. Begitu pula dengan belajar yang merupakan proses dalam diri individu yang berinteraksi dengan lingkungan untuk mendapatkan perubahan dalam perilakunya [12].Hasil belajar adalah pola-pola perbuatan, nilai-nilai, pengertianpengertian, sikap-sikap, apresiasi dan keterampilan [13]. Dalam proses evaluasi tersebut, siswa diberi beberapa tes di akhir proses belajar. Penggunaaan tes ini dimaksudkan untuk mendapatkan data tentang hasil belajar yang telah dicapai siswa.

Hasil belajar digolongkan kedalam tiga ranah yaitu ranah kognitif (pengetahuan), ranah afektif (sikap), dan ranah psikomotor (keterampilan) [14]. Hasil belajar ranah kognitif mencagkup pengetahuan hafalan, pemahaman, penerapan (aplikasi), analisis, sintesis dan evaluasi. Hasil belajar ranah afektif mencakup sikap, kemampuan dan penguasaan segi-segi emosional, yaitu perasaan dan nilai. Selanjutnya, hasil belajar ranah psikomotorik mencakup keterampilan-keterampilan atau gerakangerakan fisik.

\section{Metode Penelitian}

Jenis penelitian yang digunakan adalah penelitian tindakan kelas (PTK). Penelitian tindakan kelas merupakan suatu pencermatan terhadap kegiatan belajar berupa sebuah tindakan yang sengaja dimunculkan dan terjadi dalam sebuah kelas secara bersama [15]. Penelitian ini dilaksanakan di SMP Negeri 22 Mataram yang terletak di Jalan Gontoran Kelurahan Bertais Kecamatan Sandubaya, Kota Mataram. Waktu penelitian dimulai dari penetapan judul pada bulan September 2014 sampai dengan penyusunan laporan akhir pada bulan Mei 2015. Subyek penelitian ini adalah siswa kelas VIII A SMP Negeri 22 Mataram tahun pelajaran 2014/2015, sedangkan obyek penelitian ini adalah peningkatan aktivitas dan hasil belajar siswa. Dalam penelitian ini faktor yang diteliti adalah faktor siswa yaitu dengan melihat peningkatan aktivitas dan hasil belajar siswa.

Pelaksanaan Penelitian Tindakan Kelas (PTK) ini dilaksanakan secara bersiklus, dengan target nilai masing-masing individu minimal 75 (kriteria ketuntasan klasikal) sedangkan ketuntasan klasikal $\geq$ $85 \%$. Jika dalam siklus I target tersebut belum tercapai, maka dilanjutkan ke siklus II. Aktivitas belajar siswa dianalisis secara deskriptif berdasarkan deskriptor yang muncul pada lembar observasi aktivitas siswa, sedangkan hasil belajar siswa ranah kognitif dianalisis menggunakan tes pilihan ganda yang diberikan pada akhir tiap siklus. Untuk hasil belajar siswa ranah afektif dan psikomotor dianalisis menggunakan lembar observasi perilaku dan lembar unjuk kerja siswa. Tahapan penelitian ini terdiri dari 
(1) perencanaan tindakan, (2) pelaksanaan tindakan, (3) observasi dan evaluasi, (4) refleksi di akhir tindakan[16].

Berdasarkan hasil uji coba instrumen yang diukur dengan uji validitas, reliabilitas, taraf kesukaran, dan daya beda pada materi cahaya, untuk evaluasi siklus I dan siklus II menggunakan 25 soal. Dan penelitian ini dikatakan berhasil jika memenuhi indikator keberhasilan yakni aktivitas pembelajaran melalui implementasi model problem based learning berbantuan alat peraga minimal berada pada konversi nilai $17,5 \leq \bar{X}<22,5$ dengan kriteria aktif. Hasil belajar siswa mencapai ketuntasan klasikal $\geq$
$85 \%$ dengan nilai per siswa mencapai $\geq 75$. Hasil belajar ranah afektif siswa termasuk sikap siswa berada pada kriteria baik. Hasil belajar ranah psikomotor termasuk keterampilan observasi siswa berada pada kategori terampil.

\section{Hasil dan Pembahasan}

Penelitian ini, mengukur aktivitas dan hasil belajar siswa yang meliputi hasil belajar ranah kognitif, afektif, dan psikomotor. Adapun perbandingan aktivitas belajar siswa selama proses pembelajaran pada siklus I dan II dapat dilihat pada tabel dan grafik di bawah ini:

Tabel 2. Rekapitulasi Aktivitas Belajar Siswa pada Siklus I dan Siklus II

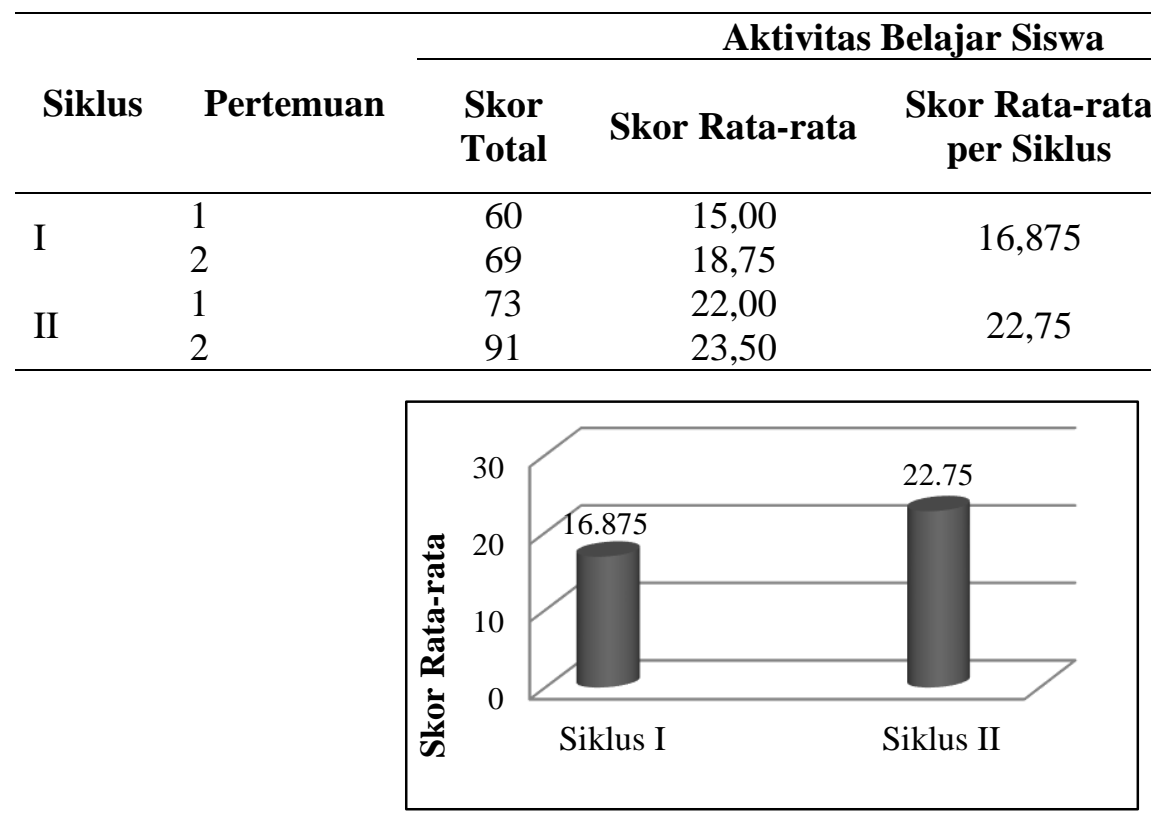

Grafik 1. Aktivitas Belajar Siswa Siklus I dan Siklus II

Berdasarkan tabel 2 dan grafik 1 di atas, terlihat adanya peningkatan aktivitas belajar siswa dari siklus I ke siklus II, bahwa skor rata-rata pada siklus I yaitu 16, 875 berada pada kriteria aktif meningkat pada siklus ke II dengan skor rata-rata yaitu 22,75 berada pada kriteria sangat aktif.

Sedangkan perbandingan hasil belajar siswa yang meliputi hasil belajar ranah kognitif, afektif, dan psikomotor pada siklus I dan II dapat dilihat pada tabel dan grafik berikut.
Tabel 3. Rekapitulasi Hasil Belajar Siswa pada Siklus I dan Siklus II

\begin{tabular}{cccc}
\hline \multirow{2}{*}{ Siklus } & \multicolumn{3}{c}{ Hasil Belajar Siswa } \\
\cline { 2 - 4 } & Kognitif & Afektif & Psikomotor \\
\hline \multirow{2}{*}{ I } & Tidak & Cukup & Cukup \\
& Tuntas & Baik & Terampil \\
\hline II & Tuntas & Baik & Terampil \\
\hline
\end{tabular}




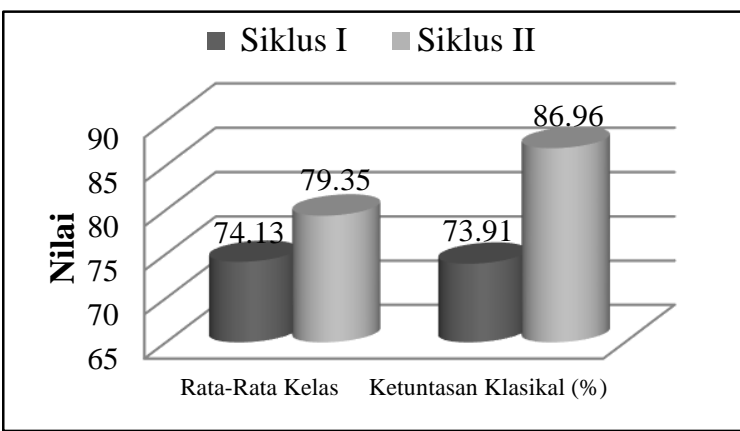

Grafik 2. Hasil Belajar Ranah Kognitif Siklus I dan Siklus II

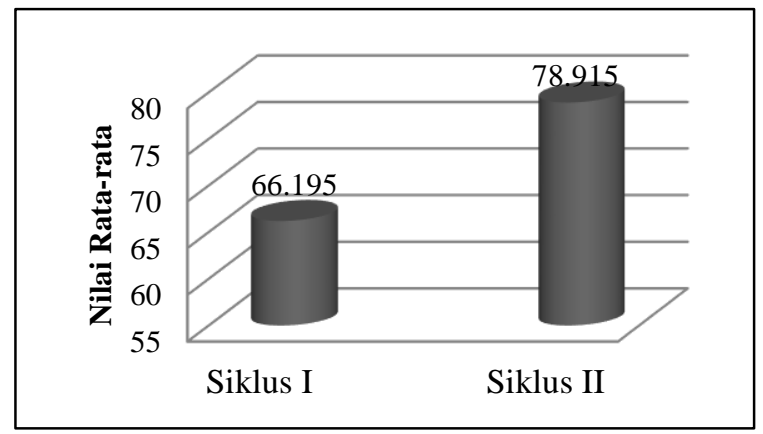

Grafik 3. Hasil Belajar Ranah Afektif Siklus I dan Siklus II

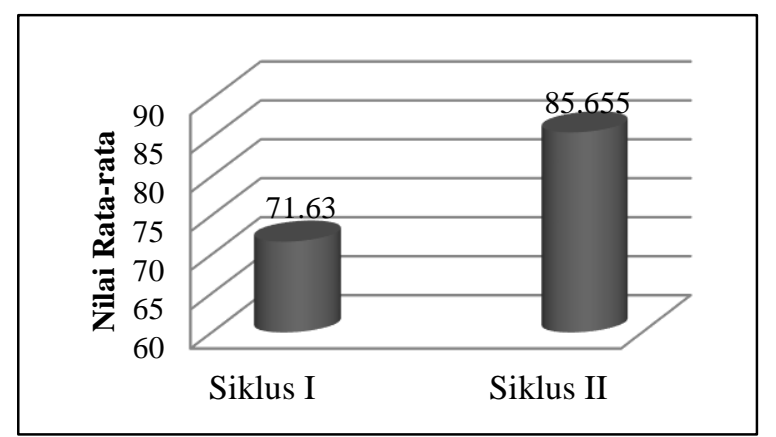

Grafik 4 Hasil Belajar Ranah Psikomotor Siklus I dan Siklus II

Berdasarkan tabel 2 dan grafik 2, 3 dan 4 tersebut, terlihat adanya peningkatan hasil belajar siswa belajar siswa dari siklus I ke siklus II. Pada siklus I hasil belajar kognitif siswa belum tuntas, hasil belajar afektif siswa masih cukup baik dan hasil belajar siswa ranah psikomotor juga masih cukup terampil. Sedangkan, pada siklus II hasil belajar kognitif siswa telah tuntas, hasil belajar afektif siswa sudah baik dan hasil belajar siswa ranah psikomotor juga sudah terampil.

Berdasarkan hasil yang telah diperoleh, pada siklus I, data aktivitas belajar siswa berada pada kategori cukup aktif dan data ini menunjukkan bahwa indikator keberhasilan untuk aktivitas belajar siswa belum mencapai keberhasilan karena belum berada pada kategori aktif. Sejalan dengan hal tersebut, hasil belajar siswa pada ranah kognitif belum mencapai indikator keberhasilan, karena siswa yang memperoleh nilai $\geq 75$ masih berada di bawah $85 \%$ yaitu73,91\%, tidak tuntasnya hasil belajar siswa pada ranah kognitif oleh beberapa faktor diantaranya: (1) siswa belum mengerjakan soal evaluasi secara individu dengan tidak mengandalkan kemampuannya sendiri, (2) siswa masih banyak yang tidak menguasi materi pelajaran dan (3) masih terdapat siswa yang mencontek saat mengerjakan soal evaluasi. Sedangkan untuk hasil belajar siswa ranah afektif belum mencapai keberhasilan karena belum berada pada kriteria baik begitu juga dengan hasil belajar siswa ranah psikomotorik belum mencapai keberhasilan karena belum berada pada kriteria terampil. Hal ini terjadi, karena terdapat beberapa kekurangan-kekurangan ketika dalam proes pembelajaran, diantaranya:(1) kesiapan siswa untuk menerima pelajaran, (2) memperhatikan penjelasan guru, (3) melakukan penyelidikan untuk memecahkan masalah, (4) membuat dan menyajikan laporan dan (5) menyimpulkan materi. Berdasarkan kekurangan tersebut, maka peneliti melakukan perbaikan untuk melanjutkan proses pembelajaran ke siklus II.

Pada siklus II diperoleh data bahwa aktivitas belajar siswa berada pada kriteria sangat aktif. Begitu juga dengan hasil belajar baik pada ranah kognitif, afektif dan psikomotor. Pada ranah kognitif ketuntasan klasikal hasil belajar kognitif siswa mencapai 86,96\%. Sedangkan, hasil belajar siswa ranah afektif dan psikomotor juga mencapai keberhasilan karena berada pada kriteria aktif dan terampil. Jadi, dapat disimpulkan bahwa hasil belajar untuk ketiga ranah hasil belajar pada siklus II telah berhasil karena memenuhi indikator keberhasilan.

Peningkatan aktivitas dan hasil belajar disebabkan oleh faktor guru dan siswa. Guru dalam menyampaikan materi sudah sistematis mulai dari materi mudah ke sulit, membantu siswa memahami permasalahan yang diberikan, guru juga menyediakan sumber belajar, memotivasi, serta membimbing siswa dalam melakukan proses penyelidikan. Proses penyelidikan yang dibantu oleh alat peraga mampu meningkatkan aktivitas siswa, meningkatkan pemahaman siswa terhadap konsep atau materi, menciptakan pembelajaran yang 
menarik dan menyenangkan, sehingga berdampak pada peningkatan hasil belajar siswa.

Berdasarkan hasil penelitian yang diperoleh melalui implementasi model Problem Based Learning berbantuan alat peraga yang telah dilakukan dalam penelitian ini dapat memberi manfaat positif bagi siswa dan guru, bahwa model PBL mendorong siswa untuk belajar secara aktif, mendorong terciptanya kolaboratif dan mampu meningkatkan kualitas pendidikan [17]. Penggunaan alat peraga dalam pengajaran juga melengkapi proses belajar supaya lebih menarik perhatian siswa, mempercepat proses belajar mengajar. Dengan perkataan lain menggunakan alat peraga, hasil belajar yang akan dicapai akan tahan lama diingat siswa, sehingga pelajaran mempunyai nilai tinggi [18].

\section{Penutup}

Berdasarkan hasil penelitian dan pembahasan dapat disimpulkan bahwa implementasi model Problem Based Learning berbantuan alat peraga dapat meningkatkan aktivitas dan hasil belajar fisika siswa di kelas VIII.A SMP Negeri 22 Mataram tahun pelajaran 2014/2015 pada pokok bahasan Cahaya.

Adapun saran-saran yang dapat diberikan adalah sebagai berikut:

1. Bagi guru fisika diharapkan dapat menerapkan model problem based learning berbantuan alat peraga sebagai salah satu upaya untuk meningkatkan aktivitas dan hasil belajar fisika siswa serta dapat mengembangkan sikap kreativitas dalam proses pembuatan alat peraga sebagai media pembelajaran di kelas.

2. Bagi peneliti untuk memperhatikan alokasi waktu selama proses pembelajaran sehingga setiap tahap kegiatan berjalan dengan baik.

Bagi peneliti lain yang ingin meneliti dengan penerapan model problem based learning berbantuan alat peraga diharapkan dapat menerapkannya pada materi yang lain.

\section{UCAPAN TERIMA KASIH}

Terima kasih penulis ucapkan kepada bapak Didik Syamsul Hadi, S.Pd., Kepala SMPN 22 Mataram, atas izin penelitian dan fasilitas yang diberikan dan bapak Ida Bagus Bangli S, S. Pd., selaku guru mata pelajaran fisika, serta seluruh siswa kelas VIII A SMPN 22 Mataram tahun pelajaran 2014/2015 yang telah ikut serta dalam penelitian ini.

\section{REFERENSI}

[1] Hikmawati dan Gunada, I.W. 2014. Kajian Fisika SMA. Mataram: FKIP Press.

[2] Hapsoro, C. A. dan Susanto, A. 2011. Penerapan Pembelajaran Problem Based Instruction Berbantuan Alat Peraga Pada Materi Cahaya di SMP. Jurnal Pendidikan Fisika Indonesia, Volume 7 Tahun 2011: 28-32. Diakses tanggal 5 Desember 2014.

[3] Kharida, L.A., Rusilowati, A. dan Pratiknyo, K. 2009. Penerapan Model Pembelajaran Berbasis Masalah Untuk Peningkatan Hasil Belajar Siswa Pada Pokok Bahasan Elastisitas Bahan. Jurnal Pendidikan Fisika Indonesia, Volume 5 Tahun 2009: 83-89. Diakses tanggal 10 Oktober 2014.

[4] Sambudi, A. dan Mosik. 2009. Penggunaan Alat Peraga Papan Optik Untuk Meningkatkan Hasil Belajar Pemantulan Cahaya Pada Siswa Kelas VIII. Jurnal Pendidikan Fisika Indonesia, Volume 5 Tahun 2009: 31-36. Diakses tanggal 3 Oktober 2014.

[5] Hikmawati. 2014. Strategi Pembelajaran Fisika. Mataram: FKIP Press.

[6] Trianto. 2007. Model-model Pembelajaran Inovatif Berorientasi Kontruktivisme. Jakarta: Prestasi Pustaka Publisher.

[7] Rusman. 2011. Model-Model Pembelajaran Mengembangkan Profesionalisme Guru. Jakarta: Rajawali Pers.

[8] Suprijono, A. 2013. Cooperataive Learning teori dan aplikasi PAIKEM. Yogyakarta: Pustaka Pelajar.

[9] Asyhar, R. 2012. Kreatif Mengembangkan Media Pembelajaran. Jakarta: Referensi.

[10] Djamarah S. B. 2010. Guru dan Anak Didik dalam Interaksi Edukatif. Jakarta: Rineka Cipta. 
[11] Hamalik, O. 2010. Proses Belajar Mengajar. Jakarta: Bumi Aksara.

[12] Purwanto. 2011. Evaluasi Hasil Belajar. Yogyakarta: Pustaka Pelajar.

[13] Suprijono, A. 2013. Cooperataive Learning teori dan aplikasi PAIKEM. Yogyakarta: Pustaka Pelajar.

[14] Arikunto, S. 2009. Dasar-Dasar Evaluasi Pendidikan. Jakarta: Bumi Aksara.

[15] Arikunto, S., Suhardjono, dan Supardi. 2012. Penelitian Tindakan Kelas. Jakarta: Bumi Aksara.

[16] Uno, H. B., Koni, S., dan Lamatenggo, N. 2012. Menjadi Peneliti PTK yang Profesional. Jakarta: Bumi Aksara.

[17] Sudjana, N. 2013. Dasar-Dasar Proses Belajar Mengajar. Bandung: Sinar Baru Algensindo.

[18] Abidin, Y. 2014. Desain Pembelajaran dalam Konteks Kurikulum 2013. Bandung: PT Refika Aditama.

\section{Biografi Penulis}

Baiq Ewik Jiniarti, lahir di sebuah desa kecil di Lombok tengah, tepatnya di Desa Marong tanggal 27 juni 1993 silam. Penulis menyelesaikan bangku pendidikan SD pada tahun 2005 di SDN 4 Marong, SMP pada tahun 2008 di SMPN 4 Praya Timur dan SMA pada tahun 2011 di SMAN 1 Praya. Kemudian melanjutkan studi S-1 di Universitas Mataram pada program studi pendidikan fisika hingga meraih gelar sarjana tahun 2015. 